\title{
A simple mixing explanation for late Pleistocene changes in the Pacific-South Atlantic benthic $\delta^{13} \mathrm{C}$ gradient
}

\author{
L. E. Lisiecki \\ Department of Earth Science, University of California, Santa Barbara, USA \\ Received: 30 November 2009 - Published in Clim. Past Discuss.: 23 December 2009 \\ Revised: 1 April 2010 - Accepted: 27 April 2010 - Published: 7 May 2010
}

\begin{abstract}
The fact that the deep-ocean benthic $\delta^{13} \mathrm{C}$ minimum shifted from the North Pacific to the South Atlantic during the Last Glacial Maximum is often interpretted as evidence of a change in deep water circulation, such as the development of deep water ventilation in the North Pacific or a decrease in Southern Ocean overturning. This study reevaluates the implications of changes in benthic $\delta^{13} \mathrm{C}$ gradients by comparing Pacific Deep Water (PDW) $\delta^{13} \mathrm{C}$ measurements with the values expected for the null hypothesis that PDW ventilation sources remained unchanged throughout the Late Pleistocene. The $\delta^{13} \mathrm{C}$ compositions of PDW, Northern Component Water (NCW) and Southern Component Water (SCW) are estimated from regional benthic $\delta^{13} \mathrm{C}$ stacks of 3-6 sites. Changes in PDW $\delta^{13} \mathrm{C}$ and PDW-SCW $\delta^{13} \mathrm{C}$ gradients over the past $800 \mathrm{kyr}$ are found to be well described by a constant mixture of $60 \% \mathrm{NCW}$ and $40 \% \mathrm{SCW}$ plus a constant Pacific remineralization offset of $-0.5 \%$. Thus, a change in PDW ventilation cannot be inferred solely on the basis of changes in the Pacific-South Atlantic benthic $\delta^{13} \mathrm{C}$ gradient.
\end{abstract}

\section{Introduction}

An important unanswered question about glacial ocean circulation is whether the shift of minimum $\delta^{13} \mathrm{C}$ values from the North Pacific to the South Atlantic at the Last Glacial Maximum (LGM) implies a major change in Pacific circulation. Benthic $\delta^{13} \mathrm{C}$ values are often used as a proxy for deep water ventilation because deep water $\delta^{13} \mathrm{C}$ becomes progressively more negative with age due to the accumulation of remineralized low $-\delta^{13} \mathrm{C}$ organic carbon. Today deep waters formed in

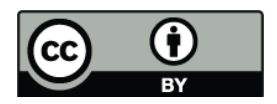

Correspondence to: L. E. Lisiecki (lisiecki@geol.ucsb.edu) the North Atlantic and Southern Ocean mix in approximately equal proportions to form Circumpolar Deep Water (CDW) (Broecker et al., 1998), which flows northward into the South Pacific at depth and returns southward at mid-depths in the form of Pacific Deep Water (PDW) (Ganachaud et al., 2003; Talley et al., 2003). Because southward flowing PDW progressively mixes with younger water during its return trip, today the oldest deep water with the most negative $\delta^{13} \mathrm{C}$ value is found at mid-depth in the North Pacific (Kroopnick, 1985; Matsumoto et al., 2002).

However, at the LGM the most negative benthic $\delta^{13} \mathrm{C}$ measurements are found in the deep South Atlantic. Does this shift imply that at the LGM Pacific deep water was younger than South Atlantic deep water? Previous studies have suggested that the change in benthic $\delta^{13} \mathrm{C}$ gradients was caused by additional mixing between PDW and North Pacific Intermediate Water (NPIW) (Duplessy et al., 1988; Herguera et al., 1992; Keigwin, 1998; Oppo and Horowitz, 2000). Alternatively, North Atlantic water may have been the primary ventilation source for the deep Pacific with intermediate water providing only a weak, secondary ventilation source (Toggweiler et al., 2006). In this study a simple mixing model is used to test the null hypothesis that PDW $\delta^{13} \mathrm{C}$ values result from a constant mixing ratio of water from the North and South Atlantic throughout the Late Pleistocene. This model reproduces most of the changes in PDW $\delta^{13} \mathrm{C}$, including glacial reversals of the Pacific-South Atlantic $\delta^{13} \mathrm{C}$ gradient.

Section 2 reviews the causes of $\delta^{13} \mathrm{C}$ variability and describes $\delta^{13} \mathrm{C}$ gradients in the ocean today and at the LGM. Section 3 estimates the $\delta^{13} \mathrm{C}$ values of PDW, Northern Component Water (NCW) and Southern Component Water (SCW) for the last $800 \mathrm{kyr}$ using regional $\delta^{13} \mathrm{C}$ stacks. Section 4 compares PDW $\delta^{13} \mathrm{C}$ with the results of a simple mixing model based on the assumption that PDW is composed of a constant proportion of NCW and SCW with a constant

Published by Copernicus Publications on behalf of the European Geosciences Union. 
remineralization offset. Section 5 discusses model and data limitations and the implications of the model results, including alternative interpretations. Finally, Sect. 6 summarizes my conclusions.

\section{Background}

Modern $\delta^{13} \mathrm{C}$ gradients are explained by differences in water masses' age and surface water processes (biological productivity and air-sea gas exchange). Here, age is defined as the length of time since water last had contact with the surface ocean. As ${ }^{13} \mathrm{C}$-depleted organic carbon sinks below the thermocline and remineralizes at depth, it increases the $\delta^{13} \mathrm{C}$ of surface water and decreases the $\delta^{13} \mathrm{C}$ of deep water. The flux of low- $\delta^{13} \mathrm{C}$ organic carbon from the surface to deep ocean produces a remineralization (or "aging") offset because the longer that deep water remains out of contact with the surface, the more negative its $\delta^{13} \mathrm{C}$ value becomes. Another important source of carbon isotope fractionation is temperature-dependent air-sea gas exchange (e.g., Mook et al., 1974; Charles et al., 1993; Lynch-Stieglitz et al., 1995), which tends to decrease the $\delta^{13} \mathrm{C}$ of warm surface water and increase the $\delta^{13} \mathrm{C}$ of cold surface water. Lastly, the global average $\delta^{13} \mathrm{C}$ of the ocean is thought to change by $-0.3 \%$ o (Duplessy et al., 1988) during glaciations as the result of a net transfer of low- $\delta{ }^{13} \mathrm{C}$ organic carbon from the continents to the ocean (Shackleton, 1977).

Today North Atlantic Deep Water (NADW), which fills most of the deep Atlantic above $4000 \mathrm{~m}$, has the highest $\delta^{13} \mathrm{C}$ of all deep water ( $\sim 1 \%$; Kroopnick, 1985$)$ because it is recently formed from surface water that experiences high biological productivity. Antarctic Bottom Water (AABW), which is formed from water with incomplete nutrient utilization, has lower $\delta^{13} \mathrm{C}$ values $(\sim 0.2$; Kroopnick, 1985$)$ and is found below $4000 \mathrm{~m}$ in the South Atlantic. Although PDW is formed from approximately equal parts NADW and AABW (Broecker et al., 1998), remineralization in the deep Pacific makes PDW $\delta{ }^{13} \mathrm{C}$ values more negative than $\mathrm{AABW}$, with a minimum value of approximately $-0.2 \%$ in the oldest water in the North Pacific (Kroopnick, 1985; Keigwin, 1998; Matsumoto et al., 2002). Alternatively, a study by Johnson (2008) suggests that PDW may be approximately $60 \%$ AABW, 20\% NADW and 20\% Antarctic Intermediate Water (AAIW).

The $\delta^{13} \mathrm{C}$ of carbonate from benthic foraminifera is used to estimate past changes in a water mass's $\delta^{13} \mathrm{C}$ composition and spatial extent. Most studies agree that epibenthic Cibicidoides species accurately record the $\delta^{13} \mathrm{C}$ of deep water (e.g., Graham et al., 1981; McCorkle et al., 1990, 1997). However, in areas of high productivity the $\delta^{13} \mathrm{C}$ of benthic foraminifera may be affected by a phytodetrital effect caused by localized remineralization of organic carbon in or at the surface of marine sediments (Mackensen et al., 1993).
Because water mass properties and formation processes differ between glacials and interglacials, I use the general term Northern Component Water (NCW) to describe intermediate/deep water formed in the North Atlantic and the term Southern Component Water (SCW) to describe deep/bottom water formed in the Southern Ocean. LGM NCW, often called Glacial North Atlantic Intermediate Water (GNAIW), shoals to $2000 \mathrm{~m}$ and has higher $\delta^{13} \mathrm{C}$ values than NCW today (Oppo and Lehman, 1993). Large changes in Atlantic $\delta^{13} \mathrm{C}$ values below $2000 \mathrm{~m}$ result from changes in the mixing ratio of $\mathrm{NCW}$ and $\mathrm{SCW}$ (i.e., more $\mathrm{SCW}$ during glacials) and the $\delta^{13} \mathrm{C}$ values of the two water masses (Curry and Oppo, 2005).

The $\delta^{13} \mathrm{C}$ value of SCW may have been as low as $-0.9 \%$ at the LGM (Ninnemann and Charles, 2002; Curry and Oppo, 2005). Repeated $\delta^{13} \mathrm{C}$ measurements of LGM benthic foraminifera from different locations throughout the South Atlantic are all consistent with a low- $\delta{ }^{13} \mathrm{C}$ glacial SCW endmember, indicating that these values are not an artifact of the phytodetrital effect (Ninnemann and Charles, 2002; Curry and Oppo, 2005). The large change in SCW $\delta^{13} \mathrm{C}$ is considered evidence for glacial reductions in air-sea exchange and overturning rates around Antarctica (e.g., Marchitto and Broecker, 2006; Bouttes et al., 2009), which could result from a northward shift in westerly winds over the Southern Ocean, increased sea ice cover, and/or increased surface stratification (Toggweiler et al., 2006). Increases in the biological productivity of the Southern Ocean may also contribute to the decrease in $\delta^{13} \mathrm{C}$ (Brovkin et al., 2007; Martinez-Garcia et al., 2009).

Because PDW is derived from a mixture of NCW and SCW that progressively accumulates low- $\delta{ }^{13} \mathrm{C}$ organic carbon during its transit, one might expect that minimum $\delta^{13} \mathrm{C}$ values would always occur in the deep Pacific. However, LGM Pacific $\delta^{13} \mathrm{C}$ measurements (although somewhat sparse) indicate that the lowest LGM Pacific $\delta^{13} \mathrm{C}$ values $(-0.4 \%$, Matsumoto et al., 2002) were much less negative than the $-0.9 \%$ values found in the deep South Atlantic. LGM reconstructions show a slight decrease in PDW $\delta^{13} \mathrm{C}$ below $2000 \mathrm{~m}$ and a slight increase above $2000 \mathrm{~m}$ (Herguera et al., 1992; Matsumoto et al., 2002). The lowest values remain in the north but shift from $2000 \mathrm{~m}$ today to $3000 \mathrm{~m}$ at the LGM (Matsumoto et al., 2002). The only observations of lower Pacific $\delta^{13} \mathrm{C}$ values $(-0.8 \%$ o) are in the western South Pacific at 2000-3000 $\mathrm{m}$ where SCW enters the Pacific (McCave et al., 2008).

Thus, during the LGM the lowest $\delta^{13} \mathrm{C}$ values are found in the South Atlantic rather than the Pacific. Does reversal of the PDW-SCW $\delta^{13} \mathrm{C}$ gradient at the LGM imply an additional source of PDW ventilation in the glacial Pacific? Some studies have proposed that NPIW ventilates glacial PDW (e.g., Duplessy et al., 1988; Herguera et al., 1992; Keigwin, 1998; Oppo and Horowitz, 2000). The flow of modified GNAIW into the Pacific may also contribute to glacial PDW ventilation (Lynch-Stieglitz and Fairbanks, 
Table 1. Core locations.

\begin{tabular}{lrrrl}
\hline Core & Lat & Long & Depth (m) & Reference \\
\hline North Atlantic & & & & \\
DSDP 552 & 56.0 & -23.2 & 2301 & Shackleton and Hall (1984) \\
ODP 658 & 20.8 & -18.7 & 2264 & Tiedemann (1991) \\
ODP 980 & 55.5 & -14.7 & 2169 & Oppo et al. (1998); McManus et al. (1999); \\
& & & & Flower et al. (2000) \\
ODP 982 & 57.5 & -15.9 & 1145 & Venz et al. (1999); Venz and Hodell (2002) \\
ODP 983 & 60.4 & -23.6 & 1983 & McIntyre et al. (1999); Raymo et al. (2004) \\
ODP 984 & 61 & -24 & 1650 & Raymo et al. (2004) \\
\hline South Atlantic & & & & \\
ODP 1089 & -40.9 & $9.9 \mathrm{E}$ & 4621 & Hodell et al. (2001) \\
ODP 1090 & -42.9 & $8.9 \mathrm{E}$ & 3702 & Venz and Hodell (2002) \\
GeoB 1211 & -24.5 & $7.5 \mathrm{E}$ & 4085 & Bickert and Wefer (1996) \\
\hline Pacific & & & & \\
ODP 677 & 4.2 & -83.7 & 3461 & Shackleton et al. (1990) \\
ODP 806B & 0.3 & 159.4 & 2520 & Berger et al. (1996); Bickert et al. (1993) \\
ODP 846 & -3.1 & -90.8 & 3307 & Mix et al. (1995a); Shackleton et al. (1995) \\
ODP 849 & 0.2 & -110.5 & 3851 & Mix et al. (1995b) \\
\hline
\end{tabular}

1994; Lynch-Stieglitz et al., 1996; Matsumoto et al., 2002; Toggweiler et al., 2006). One ocean circulation model reproduces the glacial PDW-SCW $\delta^{13} \mathrm{C}$ gradient as the result of weak ventilation primarily from NCW with no increase in mixing between PDW and Pacific intermediate waters (Toggweiler et al., 2006).

It is easy to understand how mixing with intermediate waters could ventilate the upper $2500 \mathrm{~m}$ of the glacial Pacific. Here I focus on the PDW-SCW $\delta^{13} \mathrm{C}$ reversal below $\sim 2500 \mathrm{~m}$ where the contributions of NPIW and GNAIW to PDW are most uncertain. My approach to investigating PDW ventilation sources is first to estimate the $\delta^{13} \mathrm{C}$ of the different water masses using regional $\delta^{13} \mathrm{C}$ stacks and then to compare the PDW stack with the $\delta^{13} \mathrm{C}$ values that would be expected from the null hypothesis that PDW ventilation sources and the Pacific remineralization offset remained constant throughout the late Pleistocene. This allows for better quantification of how the relationships between NCW, SCW, and PDW may have changed during glacial cycles.

\section{Regional $\delta^{13} \mathrm{C}$ stacks}

Changes in the $\delta^{13} \mathrm{C}$ of NCW, SCW, and PDW over the last $800 \mathrm{kyr}$ are estimated by stacking (averaging) $\delta^{13} \mathrm{C}$ records of Cibicidoides benthic foraminifera from each region. The stacks include all of the continuous records for each water mass spanning 0-800 ka with a temporal resolution of $\leq 5 \mathrm{kyr}$ (Table 1; Fig. 1). The age model for each $\delta^{13} \mathrm{C}$ record is produced by aligning the core's benthic $\delta^{18} \mathrm{O}$ record to the LR04 benthic $\delta^{18} \mathrm{O}$ stack (Lisiecki and Raymo, 2005). The age model uncertainty associated with this alignment is $\sim 2 \mathrm{kyr}$ within each ocean basin, but Pacific $\delta^{18} \mathrm{O}$ may briefly lag Atlantic $\delta^{18} \mathrm{O}$ by as much as $4 \mathrm{kyr}$ during terminations (Skinner and Shackleton, 2005; Lisiecki and Raymo, 2009).

The $\delta^{13} \mathrm{C}$ of NCW (Fig. 2a) is estimated by stacking six North Atlantic records from water depths of $\leq 2300 \mathrm{~m}$ (Table 1). These benthic $\delta^{13} \mathrm{C}$ records are all similar with little glacial-interglacial change (Raymo et al., 2004; Lisiecki et al., 2008) but with low-frequency power that may represent long-term cyclicity in the global carbon cycle (Raymo et al., 1997; Wang et al., 2004). The $\delta^{13} \mathrm{C}$ of SCW is estimated using three South Atlantic cores from $\geq 3700 \mathrm{~m}$ water depth: ODP 1089, ODP 1090, and GeoB1211 (Fig. 1a). This stack may not represent a pure SCW signal because ODP Site 1090 is estimated to be $60 \% \mathrm{SCW}$ and $40 \% \mathrm{NCW}$ today (Venz and Hodell, 2002). However, the NCW contribution is likely smaller during glacials. The effects of NCW intrusions at SCW sites are discussed in Sect. 5.1. The Pacific stack is composed of three records from $3300-3850 \mathrm{~m}$ depth in the Eastern Equatorial Pacific (ODP 677, ODP 846, and ODP 849 ) and one record from $2520 \mathrm{~m}$ in the Western Equatorial Pacific (ODP 806B). The $\delta^{13} \mathrm{C}$ records from these sites are similar to one another (Fig. 1b) and to shorter records from the North Pacific (Keigwin, 1998), the southeast Pacific (Matsumoto and Lynch-Stieglitz, 1999), and other western equatorial Pacific sites (Herguera et al., 1992; Mix et al., 1991). The PDW and SCW $\delta^{13} \mathrm{C}$ stacks (Fig. 2a) are well correlated $(r=0.78)$, but the glacial-interglacial amplitude of PDW $\delta^{13} \mathrm{C}$ is only about half that of SCW $\delta^{13} \mathrm{C}$. PDW $\delta^{13} \mathrm{C}$ is slightly more negative than SCW $\delta^{13} \mathrm{C}$ during interglacials but much more positive than SCW during glacials. 

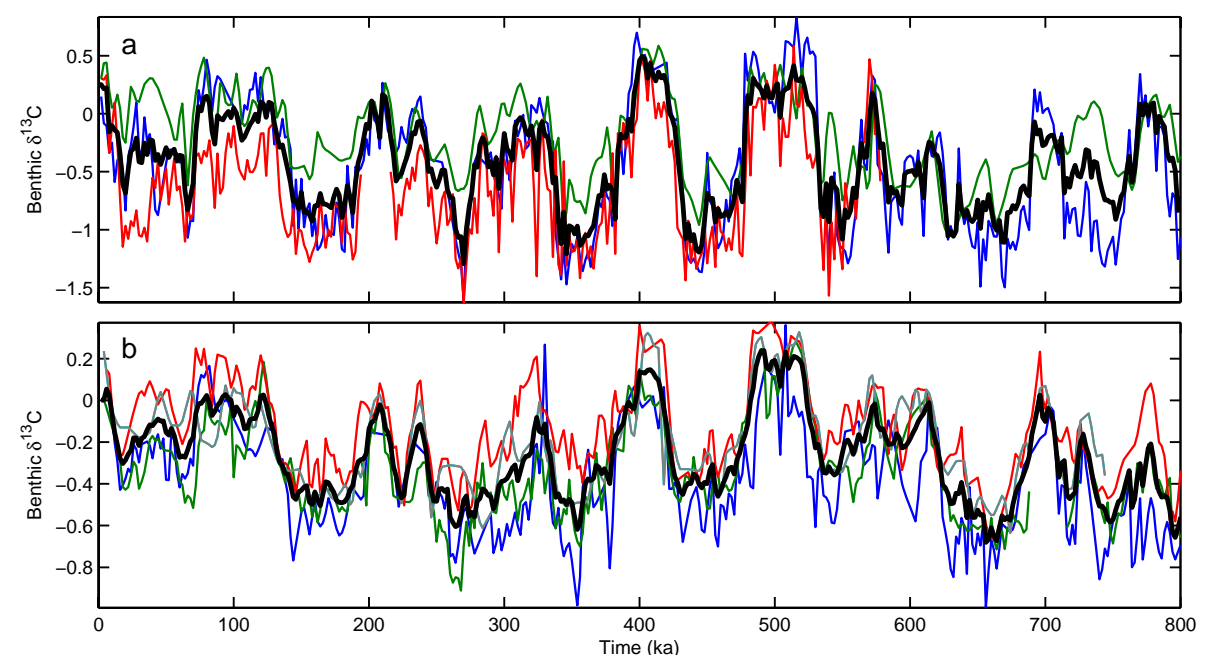

Fig. 1. Component records for (a) the SCW $\delta^{13} \mathrm{C}$ stack (black): ODP 1090 (blue), ODP 1089 (red), and GeoB1211 (green) and (b) the PDW $\delta^{13} \mathrm{C}$ stack (black): ODP 677 (blue), ODP 806 (gray), ODP 846 (green), and ODP 849 (red). See Table 1 for citations.

\section{A simple mixing model}

Reversal of the PDW-SCW $\delta^{13} \mathrm{C}$ gradient during glacials has sometimes been interpretted as evidence of a change in PDW ventilation. However, the implications of past changes in the PDW-SCW $\delta^{13} \mathrm{C}$ gradient are best evaluated in comparison with the null hypothesis that PDW ventilation remained unchanged throughout the Late Pleistocene. The PDW $\delta^{13} \mathrm{C}$ values expected for the null hypothesis are simulated using a simple mixing model that assumes PDW is derived from a constant mixing ratio of NCW and SCW plus a constant remineralization (age) offset. This is given by the equation

$\delta^{13} C_{\mathrm{PDW}}=f \delta^{13} C_{\mathrm{NCW}}+(1-f) \delta^{13} C_{\mathrm{SCW}}+c$

where $f$ is the fraction of PDW originating from the North Atlantic and $c$ is the (negative) $\delta^{13} \mathrm{C}$ offset produced by the remineralization of organic carbon in the deep Pacific. The mixing ratio $f$ and remineralization offset $c$ are estimated empirically by minimizing the root mean square error between the model and the PDW stack for $800-0 \mathrm{ka}$, yielding values of 0.60 for $f$ and $-0.51 \%$ ofor $c$. In other words, the best fit between the model and data is produced by a mixture of $60 \% \mathrm{NCW}$ and $40 \%$ SCW with a $-0.5 \%$ remineralization offset between the Atlantic and Pacific. The model estimates a greater percentage of NCW than in PDW today (Broecker et al., 1998; Johnson, 2008), but this discrepancy may be an artifact of interglacial intrusions of NCW at SCW sites (see Sect. 5.1).

Given the simplicity of the model, the overall fit between model and data is quite good for the entire Late Pleistocene (Fig. 2b), with a correlation coefficient of 0.87 and a root mean square error of $0.13 \%$. The model also reproduces the reversal of the PDW-SCW $\delta^{13} \mathrm{C}$ gradient during glacials without any change in the mixing ratio of $\mathrm{NCW}$ and $\mathrm{SCW}$ or the Pacific remineralization offset. During interglacials when the $\delta^{13} \mathrm{C}$ gradient between NCW and SCW is relatively small, the Pacific remineralization offset is sufficiently large to make PDW $\delta^{13} \mathrm{C}$ more negative than $\mathrm{SCW} \delta^{13} \mathrm{C}$. However, during glacials when the NCW-SCW gradient is large, the (constant) remineralization offset is not large enough to make PDW $\delta^{13} \mathrm{C}$ more negative than SCW $\delta^{13} \mathrm{C}$. Thus, the null hypothesis cannot be rejected solely on the basis of $\delta^{13} \mathrm{C}$ gradients. Other possible constraints on PDW ventilation are discussed in Sects. 5.2 and 5.4.

\section{Discussion}

\subsection{Data limitations}

One important limitation to evaluating the null hypothesis of constant PDW ventilation is the spatial and temporal resolution of Late Pleistocene benthic $\delta^{13} \mathrm{C}$ data. The $\delta^{13} \mathrm{C}$ of $\mathrm{NCW}$ is fairly well constrained by data from six sites above $2300 \mathrm{~m}$ in the North Atlantic. However, there is some evidence for $\delta^{13} \mathrm{C}$ gradients between different NCW components (Matsumoto and Lynch-Stieglitz, 1999; Millo et al., 2006), particularly before $600 \mathrm{kyr}$ ago (Raymo et al., 2004). In the Pacific and South Atlantic, the availablility of $\delta^{13} \mathrm{C}$ data is limited by poor carbonate preservation in these regions. This creates uncertainty about how well the PDW and $\mathrm{SCW} \delta^{13} \mathrm{C}$ stacks describe their respective water masses.

The strong similarity of all four Pacific $\delta^{13} \mathrm{C}$ records (Fig. 1a) suggests that the PDW stack is probably a good representation of $\delta^{13} \mathrm{C}$ values from $2500-3850 \mathrm{~m}$ in the equatorial Pacific. The lack of strong $\delta^{13} \mathrm{C}$ gradients in the Pacific below $2000 \mathrm{~m}$ today and during the LGM (Herguera et al., 1992; Matsumoto et al., 2002) suggests that the PDW stack may also be representative of a large portion of the 


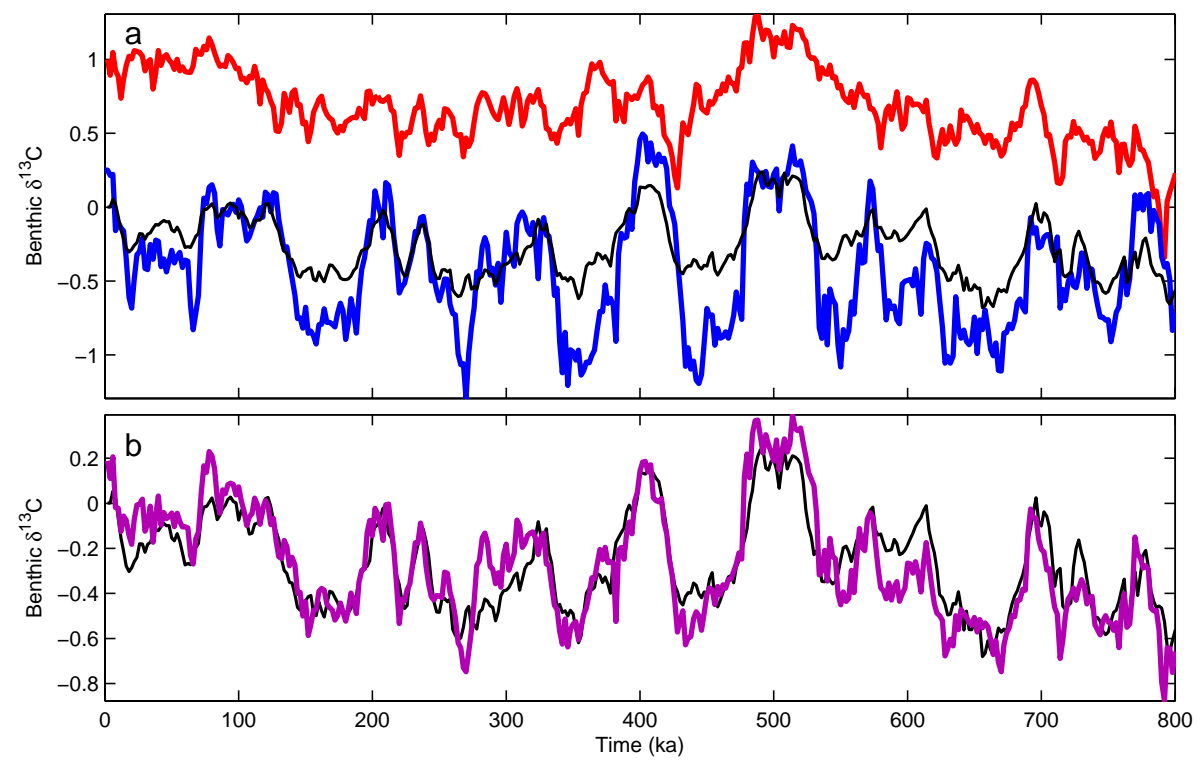

Fig. 2. (a) Regional stacks of $\delta^{13} \mathrm{C}$ for NCW (red), SCW (blue), and PDW (black), (b) PDW $\delta^{13} \mathrm{C}$ stack (black) and the $\delta^{13} \mathrm{C}$ predicted by the null hypothesis (purple), simulated by a constant mixture of $60 \%$ NADW and $40 \%$ CDW plus a remineralization offset of $-0.5 \%$. This simple mixing model produces a good fit with changes in PDW $\delta^{13} \mathrm{C}$ and the PDW-SCW $\delta^{13} \mathrm{C}$ gradient.

deep Pacific. However, because glacial Pacific $\delta^{13} \mathrm{C}$ data are relatively scarce, possible spatial variability in PDW $\delta^{13} \mathrm{C}$ is discussed below. Another limitation of the PDW stack is the relatively low temporal resolution (2.4-4.8 kyr) of its component records, which prevents analysis of millennial-scale changes in ventilation. Thus, this study only assesses the relative contributions of NCW and SCW to PDW on orbital timescales, with results that likely reflect the average contribution of each water mass over several thousand years.

The SCW stack is probably the most susceptible to error, particularly from $800-600 \mathrm{ka}$, where the stack includes only two $\delta^{13} \mathrm{C}$ records which differ by as much as $1 \%$. Gradients between SCW sites are likely caused by variable mixing with NCW; for example, modern deep water at ODP Site 1090 is $40 \%$ NCW (Venz and Hodell, 2002). The SCW data cannnot easily be corrected for this effect because the NCW intrusions change through time, with larger NCW contributions during interglacials than glacials. This increases the apparent amplitude of SCW $\delta^{13} \mathrm{C}$ change and may cause the model to underestimate the SCW contribution to PDW. Decreasing the amplitude of the SCW stack by $20 \%$ as a possible correction for the effects of interglacial $\mathrm{NCW}$ intrusions yields a best-fit model estimate that PDW has been derived from 50\% $\mathrm{NCW}$ and $50 \% \mathrm{SCW}$ for the past $800 \mathrm{kyr}$, in agreement with estimates of modern contributions based on radiocarbon and pre-formed phosphate distributions (Broecker et al., 1998).

\subsection{Model limitations and alternative interpretations}

An additional concern is that the simple mixing model presented here cannot adequately test for all possible changes in PDW ventilation even if the $\delta^{13} \mathrm{C}$ values of NCW, SCW, and PDW are known exactly. A unique solution can be found only if no other water masses contribute to PDW and if either $f$ or $c$ is assumed to be constant. Changes in the relative flux of NCW into the Pacific could be disguised by compensating variations in the Pacific remineralization offset, potentially resulting from changes in overturning rates, the $\delta^{13} \mathrm{C}$ of sinking organic matter, or Pacific surface productivity (e.g., Robinson et al., 2005). More research is needed to constrain the extent to which the Pacific remineralization offset may have varied over the last $800 \mathrm{kyr}$.

The ventilation of PDW by water masses other than NCW and SCW would also produce errors in the model's estimates of the PDW mixing ratio and remineralization offset. NPIW is sometimes cited as a possible additional ventilation source for glacial PDW (e.g., Duplessy et al., 1988; Herguera et al., 1992; Keigwin, 1998). Increased production and deeper mixing of NPIW may explain higher $\delta^{13} \mathrm{C}$ values at $2000 \mathrm{~m}$ in the Pacific, but sharp gradients in $\delta^{13} \mathrm{C}, \delta^{18} \mathrm{O}$, and apparent ventilation age between $2000 \mathrm{~m}$ and $3000 \mathrm{~m}$ at the LGM suggest strong density stratification and little mixing with NPIW below $3000 \mathrm{~m}$ (Matsumoto et al., 2002). Latitudinal $\delta^{13} \mathrm{C}$ gradients are also inconsistent with NPIW ventilation. LGM $\delta^{13} \mathrm{C}$ values at $3000 \mathrm{~m}$ in the North Pacific (near the possible ventilation source) are more negative than $\mathrm{LGM} \delta^{13} \mathrm{C}$ values at $3000 \mathrm{~m}$ in the equatorial Pacific (Matsumoto et al., 2002). 
Could additional PDW ventilation occur in the South Pacific? One study estimates that AAIW constitutes up to $20 \%$ of modern PDW at $3000 \mathrm{~m}$ (Johnson, 2008). Because glacial $\delta^{13} \mathrm{C}$ values for AAIW are approximately 0\%o (Pahnke and Zahn, 2005), AAIW contributions to PDW could also help explain why glacial PDW has a more positive $\delta^{13} \mathrm{C}$ value than glacial SCW. Therefore, the estimated contributions of NCW and SCW from the simple mixing model should not be considered definitive. However, a simulation of glacial ocean circulation reproduces the PDW-SCW $\delta^{13} \mathrm{C}$ gradient without any increase in mixing between AAIW and PDW at the LGM (Toggweiler et al., 2006). Additionally, if mixing with AAIW were the primary source of PDW ventilation, one would expect PDW $\delta^{13} \mathrm{C}$ values to be more positive near the source of AAIW ventilation and more negative at greater distances from the ventilation source. Thus, the deepest Pacific site would be expected to have the most negative $\delta^{13} \mathrm{C}$ values. Instead, ODP Site 849 at $3851 \mathrm{~m}$ is more positive than the two shallower EEP sites (Fig. 1b).

Another possible southern ventilation source is suggested by an LGM depth profile of $\delta^{13} \mathrm{C}$ in the Southwest Pacific, which detects an additional water mass below $3500 \mathrm{~m}$ with a $\delta^{13} \mathrm{C}$ value of $-0.3 \%$ (Cibicidoides-equivalent as measured in Uvigerina) (McCave et al., 2008). McCave et al. (2008) propose that this water mass represents deep water formed in the Ross Sea and that topographic barriers at $3500 \mathrm{~m}$ in the Southern Ocean prevent dense, low- $\delta{ }^{13} \mathrm{C}$ glacial deep water formed in the Weddell Sea from entering the Pacific below $3500 \mathrm{~m}$. This does not necessarily imply a change in PDW ventilation; instead, the apparent shift may arise because Ross and Weddell Sea waters are indistinguishable during interglacials and only develop different $\delta^{13} \mathrm{C}$ and $\mathrm{Cd} / \mathrm{Ca}$ signatures during glacials (Rosenthal et al., 1997; Ninnemann and Charles, 2002; McCave et al., 2008). However, the paleoextent of Ross Sea Water is difficult to assess because LGM $\delta^{13} \mathrm{C}$ transects in the low and mid-latitude Pacific show no $\delta^{13} \mathrm{C}$ gradients below $2000 \mathrm{~m}$ (Herguera et al., 1992; Matsumoto et al., 2002; McCave et al., 2008). Additional study is needed to determine the extent to which Ross Sea Water may have influenced PDW $\delta^{13} \mathrm{C}$.

\subsection{Model-data residuals}

The simple mixing model presented here provides no evidence for glacial changes in the mixing ratio of NCW and $\mathrm{SCW}$ or for a long-term trend in their relative contributions to the Pacific over the last $800 \mathrm{kyr}$. Separately analyzing the time intervals $800-400 \mathrm{ka}$ and $400-0 \mathrm{ka}$ yields estimates of $60 \%$ and $62 \% \mathrm{NCW}$, respectively. However, the Pacific remineralization offset shifts from $-0.47 \%$ o to $-0.58 \%$ o between the two intervals. Possible mechanisms for a long-term trend in the remineralization offset are changes in the rate of deep water export to the Pacific or changes in the flux or $\delta^{13} \mathrm{C}$ composition of carbon falling from the surface ocean.
For the 800-0 ka model, model-data residuals are all less than $0.4 \% o$ (Fig. 2b). Several short intervals with average residuals of $\geq 0.1 \%$ occur at: $635-575 \mathrm{ka}(-0.17 \%$ o), 530$475 \mathrm{ka}(0.13 \%$ o), 325-275 $\mathrm{ka}(0.14 \%$ o $)$ and $80-0 \mathrm{ka}(0.11 \%$ ). The durations of these model-data misfits are insufficient to determine whether they are caused by changes in the ratio of NCW or the Pacific remineralization offset. For example, the best fit for $80-0 \mathrm{ka}$ is obtained from a mixture of $66 \%$ $\mathrm{NCW}$ and a $0.69 \%$ o Pacific remineralization offset, but the fit for $60 \% \mathrm{NCW}$ and a $0.62 \%$ Pacific remineralization offset is nearly as good. The two scenarios have less than a 5\% difference in root mean square error. Alternatively, some of these model-data residuals may result from temporary intrusions of NCW at SCW sites, which would cause the model to overestimate PDW $\delta^{13} \mathrm{C}$. This is not a likely explanation for residuals during glacial conditions when NCW is less extensive, but NCW intrusions could explain residuals during interglacial intervals, such as 530-475 ka and 325-275 ka.

\subsection{Additional tests of the null hypothesis}

The null hypothesis (a constant mixing ratio of NCW and SCW with a constant Pacific remineralization offset) reproduces the reversal of the PDW-SCW $\delta^{13} \mathrm{C}$ gradient during glacials without any changes in PDW ventilation. However, this requires that the relative contribution of NCW to PDW at 2500-3850 $\mathrm{m}$ remain approximately constant despite dramatic shoaling of NCW in the glacial Atlantic. One can further test the null hypothesis by assessing whether glacial $\mathrm{NCW}$ reached the deep Pacific and constraining the relative export rates of NCW and SCW.

Because NCW must pass through the South Atlantic to reach the deep Pacific, one possible test of the null hypothesis is identification of NCW in the South Atlantic. Glacial $\delta^{13} \mathrm{C}$ values were approximately $0.2 \%$ at $\sim 3000 \mathrm{~m}$ in the western South Atlantic (Curry and Oppo, 2005; Lisiecki et al., 2008), which suggests an approximately equal mixture of NCW $(1.2 \%)$ and SCW (-0.8\%o). Additionally, a vertical $\delta^{13} \mathrm{C}$ profile at $\sim 45^{\circ} \mathrm{S}$ in the eastern Atlantic has an LGM $\delta^{13} \mathrm{C}$ value of $\sim 0 \%$ at $2500 \mathrm{~m}$, indicative of substantial mixing between NCW and SCW (Hodell et al., 2003). Could $\mathrm{NCW}$ at $\sim 2500 \mathrm{~m}$ in the South Atlantic reach the glacial deep Pacific? Possible routes of GNAIW through the Southern Ocean are highly speculative because glacial benthic $\delta^{13} \mathrm{C}$ measurements south of $50^{\circ} \mathrm{S}$ are nearly nonexistent. The Antarctic Circumpolar Current may have been highly effective at mixing GNAIW to sill depths of $3500 \mathrm{~m}$ en route to the Pacific or GNAIW may have reached the deep Pacific via deep water formation in the Ross Sea (McCave et al., 2008). Alternatively, some studies have suggested that NADW formation continued throughout the glaciation (Matsumoto and Lynch-Stieglitz, 1999; Millo et al., 2006).

If NCW reached the glacial deep Pacific, could its export rate have been comparable to that of SCW? Estimates of the glacial overturning rates of NCW and SCW vary widely (e.g., 
Toggweiler et al., 2006; Weber et al., 2007; Huybers et al., 2007; Govin et al., 2009; Bouttes et al., 2009), and their flux into the Pacific is even more difficult to constrain. $\mathrm{Pa} / \mathrm{Th}$ data suggest that the rate of North Atlantic overturning at the LGM was nearly as high as in the Holocene (McManus et al., 2004). Export of at least some GNAIW into the Pacific is supported by identification of the air-sea exchange signature of GNAIW in the glacial Pacific (Lynch-Stieglitz et al., 1996) and analysis of $\delta^{13} \mathrm{C}$ gradients between the open Pacific and Tasman Sea (Russon et al., 2009). Pore water estimates of deep water temperature and salinity during the LGM suggest that PDW may have been more similar to NCW than SCW (Adkins et al., 2002). Additionally, the simulation of glacial ocean circulation by Toggweiler et al. (2006) finds that GNAIW was the primary ventilation source for glacial PDW. More research is needed to evaluate whether the ratio of NCW and SCW fluxes into the Pacific actually remained constant.

\subsection{Water mass ages}

Finally, I consider the mixing model's implications for the relative ages of PDW and SCW at the LGM. The simple model presented here is actually consistent with either young or old glacial SCW, where age is defined as the length of time since deep water last had contact with the surface ocean. At one extreme, SCW may have remained relatively young with rapid overturning (e.g., Ninnemann and Charles, 2002; Curry and Oppo, 2005) and obtained $l o w-\delta^{13} \mathrm{C}$ values through other processes, such as reduced air-sea gas exchange (e.g., Piotrowski et al., 2008) or increased Southern Ocean productivity (e.g., Brovkin et al., 2007; MartinezGarcia et al., 2009) which would increase the accumulation of isotopically depleted carbon in the deep South Atlantic. In this case, water mass ages, overturning rates, and fluxes into the Pacific could have been quite similar to modern circulation (Huybers et al., 2007; Marchal and Curry, 2008), but benthic $\delta^{13} \mathrm{C}$ would might not correlate with ventilation age because changes in productivity or air-sea gas exchange could overwhelm the remineralization effect (e.g., Charles et al., 1993).

At the other extreme, the model results could also be consistent with a stagnant layer of old SCW in the glacial deep Atlantic (e.g., Sikes et al., 2000; Toggweiler et al., 2006; Brovkin et al., 2007; Marchitto et al., 2007). A large density gradient (Adkins et al., 2002) could have impeded vertical mixing within the Atlantic, and the 3500-m sill in the Southern Ocean would have blocked SCW flow into the deep Pacific (McCave et al., 2008). The glacial ocean circulation model of Toggweiler et al. (2006) found that SCW was ventilated in only one grid cell in the Pacific sector of the Southern Ocean. In such a scenario, the fluxes of both SCW and NCW into the Pacific would likely be reduced. A decrease in the rate of remineralization during glaciations could potentially explain why no change in the Pacific remineralization (age) offset is apparent in my simple mixing model. Glacial PDW could be younger than SCW if its age is the average of young NCW and old SCW plus an age offset that is not large enough to make it older than SCW. Radiocarbon estimates of deep water ages (e.g., Broecker et al., 2007; Marchitto et al., 2007) may provide additional constraints on changes in overturning rates.

\section{Conclusions}

Late Pleistocene changes in the $\delta^{13} \mathrm{C}$ values of NCW, SCW, and PDW are estimated from regional benthic $\delta^{13} \mathrm{C}$ stacks. Orbital-scale changes in PDW $\delta^{13} \mathrm{C}$ and the PDW-SCW $\delta{ }^{13} \mathrm{C}$ gradient are found to be well described by a constant mixture of $60 \% \mathrm{NCW}$ and $40 \% \mathrm{SCW}$ with a constant $-0.5 \%$ o Pacific remineralization offset for the last $800 \mathrm{kyr}$. Interglacial intrusions of NCW at SCW sites may explain the slight discrepancy between the model's mixing ratio estimate and the modern mixing ratio of 50\% NCW (Broecker et al., 1998). Model-data comparison also yields no evidence for a long-term trend in the NCW contribution to PDW over the last 800-kyr, but the Pacific remineralization offset may have gradually shifted from $-0.47 \%$ o to $-0.62 \%$.

A constant ratio in the flux of NCW and SCW to the deep Pacific provides the simplest explanation of glacial changes in the PDW-SCW $\delta^{13} \mathrm{C}$ gradient changes. During interglacials when the $\delta^{13} \mathrm{C}$ gradient between NCW and SCW is relatively small, the Pacific remineralization offset is sufficiently large to make PDW $\delta^{13} \mathrm{C}$ more negative than SCW $\delta^{13} \mathrm{C}$. However, during glacials when the NCW-SCW gradient is large, the (constant) remineralization offset is not large enough to make PDW $\delta^{13} \mathrm{C}$ more negative than SCW $\delta^{13} \mathrm{C}$. Thus, the null hypothesis of constant Pacific ventilation cannot be rejected on the basis of changes in the PDW-SCW $\delta^{13} \mathrm{C}$ gradient. Additionally, the pattern of $\delta^{13} \mathrm{C}$ gradients within the Pacific at the LGM does not appear to support mixing between PDW and NPIW below $3000 \mathrm{~m}$ (Matsumoto et al., 2002).

The results presented here suggest that glacial boundary conditions may not have greatly altered the relative contributions of NCW and SCW to PDW. However, a simple mixing model cannot provide conclusive results because changes in the mixing ratio of the two water masses could be disguised by changes in the Pacific remineralization rates or by contributions from other water masses such as AAIW or Ross Sea Water. More research is needed to constrain the $\delta^{13} \mathrm{C}$ composition and spatial extent of glacial water masses and changes in the Pacific remineralization offset throughout the Late Pleistocene. 
Acknowledgements. M. E. Raymo and D. W. Lea provided many helpful comments for the improvement of this manuscript. I also thank R. Toggweiler and one anonymous reviewer for their insightful suggestions. Support for this research was provided by NSF grant MGG-0926735.

Edited by: F. Peeters

\section{References}

Adkins, J. F., McIntyre, K., and Schrag, D. P.: The salinity, temperature, and $\delta^{18} \mathrm{O}$ of the glacial deep ocean, Science, 298, 17691773, 2002.

Berger, W. H., Bickert, T., Yasuda, M. K., and Wefer, G.: Reconstruction of atmospheric $\mathrm{CO}_{2}$ from ice-core data and the deepsea record of Ontong Java plateau: the Milankovitch chron, Geol. Rundsch., 85, 466-495, doi:10.1007/BF02369003, 1996.

Bickert, T., Berger, W. H., Burke, S., Schmidt, H., and Wefer, G.: Late quaternary stable isotope record of benthic foraminifers: sites 805 and 806, Ontong Java plateau, Proc. Ocean Drill. Program Sci. Results, 130, 411-420, 1993.

Bickert, T. and Wefer, G.: Late Quaternary deep water circulation in the South Atlantic: reconstruction from carbonate dissolution and benthic stable isotopes, in: The South Atlantic: Present and Past Circulation, edited by: G. Wefer, Berger, W. H., Siedler, G., and Webb, D. J., 599-620, Springer, New York, 1996.

Bouttes, N., Roche, D. M., and Paillard D.: Impact of strong deep ocean stratification on the glacial carbon cycle, Paleoceanography, 24, PA3203, doi:10.1029/2008PA001707, 2009.

Broecker, W. S., Peacock, S. L., Walker, S., Weiss, R., Fahrbach, E., Schroeder, M., Mikolajewicz, U., Heinze, C., Key, R., Peng, T.H., and Rubin, S.: How much deepwater is formed in the Southern Ocean? J. Geophys. Res., 103(C8), 15833-15843, 1998.

Broecker, W., Clark, E., Barker, S., Hajdas, I., Bonani, G., and Moreno, E.: Radiocarbon age of late glacial deep water from the Equatorial Pacific, Paleoceanography, 22, PA2206, doi:10.1029/2006PA001359, 2007.

Brovkin, V., Ganopolski, A., Archer, D., and Rahmstorf, S.: Lowering of glacial atmospheric $\mathrm{CO}_{2}$ in response to changes in oceanic circulation and marine biogeochemistry, Paleoceanography, 22, PA4202, doi:10.1029/2006PA001380, 2007.

Charles, C. D., Wright, J. D., and Fairbanks, R. G.: Thermodynamic influences on the marine carbon isotope record, Paleoceanography, 8, 691-697, 1993.

Curry, W. B., and Oppo, D. W.: Glacial water mass geometry and the distribution of $\delta^{13} \mathrm{C}$ of $\Sigma \mathrm{CO}_{2}$ in the Western Atlantic Ocean, Paleoceanography, 20, PA1017, doi:10.1029/2004PA001021, 2005.

Duplessy, J. C., Shackleton, N. G., Fairbanks, R. G., Labeyrie, L., Oppo, D. W., and Kallel, N.: Deepwater source variations during the last climatic cycle and their impact on the global deepwater circulation, Paleoceanography, 3, 343-360, 1988.

Flower, B. P., Oppo, D. W., McManus, J. F., Venz, K. A., Hodell, D. A., and Cullen, J. L.: North Atlantic intermediate to deep water circulation and chemical stratification during the past $1 \mathrm{Myr}$, Paleoceanography, 15, 388-403, 2000.

Ganachaud, A.: Large-scale mass transports, water mass formation, and diffusivities estimated from World Ocean Circulation Exper- iment (WOCE) hydrographic data, J. Geophys. Res., 108, 3213, doi:10.1029/2002JC001565, 2003.

Govin, A., Michel, E., Labeyrie, L., Waelbroeck, C., Dewilde, F., and Jansen, E.: Evidence for northward expansion of Antarctic bottom water mass in the Southern Ocean during the last glacial inception, Paleoceanography, 24, PA1202, doi:10.1029/2008PA001603, 2009.

Graham, D. W., Corliss, B. H., Bender, M. L., and Keigwin, L. D.: Carbon and oxygen isotopic disequilibria of recent deep-sea benthic foraminifera, Mar. Micropaleontol., 6, 483-497, 1981.

Herguera, J. C., Jansen, E., and Berger, W. H.: Evidence for a bathayal front at $2000 \mathrm{~m}$ depth in the glacial Pacific, based on a depth transect on Ontong Java plateau, Paleoceanography 7, 273-288, 1992.

Hodell, D. A., Charles, C. D., and Sierro, F. J.: Late Pleistocene evolution of the ocean's carbonate system, Earth Planet. Sc. Lett., 192, 109-124, 2001.

Hodell, D. A., Venz, K. A., Charles, C. D., and Ninnemann, U. S.: Pleistocene vertical carbon isotope and carbonate gradients in the South Atlantic sector of the Southern Ocean, Geochem. Geophy. Geosy., 4(1), 1004, doi:10.1029/2002GC000367, 2003.

Huybers, P., Gebbie, G., and Marchal, O.: Can paleoceanographic tracters constrain meridional circulation rates?, J. Phys. Oceanogr., 37, 394-407, 2007.

Johnson, G. C.: Quantifying Antarctic Bottom Water and North Atlantic Deep Water volumes, J. Geophys. Res., 113, C05027, doi:10.1029/2007JC004477, 2008.

Keigwin, L. D.: Glacial-age hydrography of the far Northwest Pacific Ocean, Paleoceanography, 13, 323-339, 1998.

Kroopnick, P. M.: The distribution of $\delta^{13} \mathrm{C}$ of $\Sigma \mathrm{CO}_{2}$ in the world oceans, Deep-Sea Res., 32, 57-84, 1985.

Lisiecki, L. E. and Raymo, M. E.: A Pliocene-Pleistocene stack of 57 globally distributed benthic $\delta^{18} \mathrm{O}$ records, Paleoceanography, 20, PA1003, doi:10.1029/2004PA001071, 2005.

Lisiecki, L. E., Raymo, M. E., and Curry, W. B.: Atlantic overturning responses to Late Pleistocene climate forcings, Nature, 456, 85-88, 2008

Lisiecki, L. E. and Raymo M. E.: Diachronous benthic $\delta^{18} \mathrm{O}$ responses during late Pleistocene terminations, Paleoceanography, 24, PA3210, doi:10.1029/2009PA001732, 2009.

Lynch-Stieglitz, J. and Fairbanks, R. G.: A conservative tracer for glacial ocean circulation from carbon isotope and paleonutrient measurements in benthic foraminifera, Nature, 369, 308-310, 1994.

Lynch-Stieglitz, J., Stocker, T. F., Broecker, W. S., and Fairbanks, R. G.: The influence of air-sea exchange on the isotopic composition of oceanic carbon: observations and modeling, Global Biogeochem. Cy., 9, 653-665, 1995.

Lynch-Stieglitz, J., van Geen, A., and Fairbanks, R. G.: Interocean exchange of glacial North Atlantic intermediate water: evidence from Subantarctic $\mathrm{Cd} / \mathrm{Ca}$ and carbon isotope measurements, $\mathrm{Pa}$ leoceanography, 11, 191-201, 1996.

Mackensen, A., Hubberton, H.-W., Bickert, T., Fischer, G., and Futterer, D. K.: $\delta^{13} \mathrm{C}$ in benthic foramineral tests of Fontbotia wuellerstorfi (Schwager) relative to the $\delta^{13} \mathrm{C}$ of dissolved inorganic water in Southern Ocean deep water: implications for glacial ocean circulation models, Paleoceanography, 6, 587-610, 1993.

Marchal, O. and Curry, W. B.: On the abyssal circulation in the 
glacial Atlantic, J. Phys. Oceanogr., 38, 2014-2037, 2008.

Marchitto, T. M. and Broecker, W. S.: Deep water mass geometry in the glacial Atlantic Ocean: a review of constraints from the paleonutrient proxy $\mathrm{Cd} / \mathrm{Ca}$, Geochem. Geophy. Geosy., 7, Q12003, doi:10.1029/2006GC001323, 2006.

Marchitto, T. M., Lehman, S. J., Ortiz, J. D., Fluckiger, J., and van Geen, A: Marine radiocarbon evidence for the mechanism of deglacial atmospheric $\mathrm{CO}_{2}$ rise, Science, 316, 1456-1459, 2007.

Martinez-Garcia, A., Rosell-Mele, A., Geibert, W., Gersonde, R., Masque, P., Gaspari, V., and Barbante, C.: Links between iron supply, marine productivity, sea surface temperature, and $\mathrm{CO}_{2}$ over the last $1.1 \mathrm{Ma}$, Paleoceanography, 24, PA1207, doi:10.1029/2008PA001657, 2009.

Matsumoto, K. and Lynch-Stieglitz, J.: Similar glacial and Holocene deepwater circulation inferred from Southeast Pacific benthic foraminiferal carbon isotope composition, Paleoceanography, 14, 149-163, 1999.

Matsumoto, K., Oba, T., Lynch-Stieglitz, J., and Yamamoto, H.: Interior hydrography and circulation of the glacial Pacific Ocean, Quat. Sci. Rev., 21, 1693-1704, 2002.

McCave, I. N., Carter, L., and Hall, I. R.: Glacial-interglacial changes in water mass structure and flow in the SW Pacific Ocean, Quat. Sci. Rev., 27, 1886-1908, 2008.

McCorkle, D. C., Keigwin, L. D., Corliss, B. H., and Emerson, S. R.: The influence of microhabitats on the carbon isotopic composition of deep-sea benthic foraminifera, Paleoceanography, 5, 161-185, 1990.

McCorkle, D. C., Corliss, B. H., and Farnham, C. A.: Vertical distributions and stable isotopic compositions of live (stained) benthic foraminifera from the North Carolina and California continental margins, Deep-Sea Res., 44, 983-1024, 1997.

McIntyre, K., Ravelo, A. C., and Delaney, M. L.: North Atlantic intermediate waters in the late Pliocene to early Pleistocene, $\mathrm{Pa}$ leoceanography, 14, 324-335, 1999.

McManus, J. F., Oppo, D. W., and Cullen, J. L.: A 0.5-millionyear record of millennial-scale climate variability in the North Atlantic, Science, 283, 971-974, 1999.

McManus, J. F., Francois, R., Gherardi, J.-M., Keigwin, L. D., and Brown-Leger, S.: Collapse and rapid resumption of Atlantic meridional circulation linked to deglacial climate changes, Nature, 428, 834-837, 2004.

Millo, C., Sarnthein, M., Voelker, A., and Erlenkeuser, H.: Variability of the Denmarl Strait Overflow during the Last Glacial Maximum, Boreas, 35, 50-60, 2006.

Mix, A. C., Pisias, N. G., Zahn, R., Rugh, W., Lopez, C., and Nelson, K.: Carbon 13 in Pacific deep and intermediate waters, 0$370 \mathrm{ka}$ : implications for ocean circulation and Pleistocene $\mathrm{CO}_{2}$, Paleoceanography, 6, 205-226, 1991.

Mix, A. C., Le, J., and Shackleton, N. J.: Benthic foraminiferal stable isotope stratigraphy from Site 846: 0-1.8 Ma, Proc. Ocean Drill. Program Sci. Results, 138, 839-847, 1995a.

Mix, A. C., Pisias, N. G., Rugh, W., Wilson, J., Morey, A., and Hagelberg, T. K.: Benthic foraminifer stable isotope record from Site 849 (0-5 Ma): local and global climate changes, Proc. Ocean Drill. Program Sci. Results, 138, 371-412, 1995b.

Mook, W. G., Bommerson, J. C., and Straverman, W. H.: Carbon isotope fraction between dissolved bicarbonate and gaseous carbon dioxide, Earth Planet. Sc. Lett., 22, 169-176, 1974.

Ninnemann, U. S. and Charles, C. D.: Changes in the mode of
Southern Ocean circulation over the last glacial cycle revealed by foraminiferal stable isotope variability, Earth Planet. Sc. Lett., 201, 383-396, 2002.

Oppo, D. W. and Horowitz, M.: Glacial deep water geometry: South Atlantic benthic foraminiferal $\mathrm{Cd} / \mathrm{Ca}$ and $\delta^{13} \mathrm{C}$ evidence, Paleoceanography, 15, 147-160, 2000.

Oppo, D. W. and Lehman, S. J.: Mid-depth circulation of the subpolar North Atlantic during the Last Glacial Maximum, Science, 259, 1148-1152, 1993.

Oppo, D. W., McManus, J. F., and Cullen, J. C.: Abrupt climate change events 500000 to 340000 years ago: evidence from subpolar North Atlantic sediments, Science, 279, 1335-1338, 1998.

Pahnke, K. and Zahn, R.: Southern Hemisphere water mass conversion linked with North Atlantic climate variability, Science, 307, 1741-1746, 2005.

Piotrowski, A. M., Goldstein, S. L., Hemming, S. R., Fairbanks, R. G., and Zylberberg, D. R.: Oscillating glacial northern and southern deep water formation from combined neodymium and carbon isotopes, Earth Planet. Sc. Lett., 272, 394-405, 2008.

Raymo, M. E., Oppo, D. W., and Curry, W.: The mid-Pleistocene climate transition: A deep sea carbon isotopic perspective, Paleoceanography, 12, 546-559, doi:10.1029/97PA01019, 1997.

Raymo, M. E., Oppo, D. W., Flower, B. P., Hodell, D. A., McManus, J. F., Venz, K. A., Kleiven, K. F., and McIntyre, K.: Stability of North Atlantic water masses in face of pronounced climate variability during the Pleistocene, Paleoceanography, 19, PA2008, doi:10.1029/2003PA000921, 2004.

Robinson, R. S., Sigman, D. M., DiFiore, P. J., Rohde, M. M., Mashiotta, T. A., and Lea, D. W.: Diatom-bound ${ }^{15} \mathrm{~N} /{ }^{14} \mathrm{~N}$ : New support for enhanced nutrient consumption in the ice age subantarctic, Paleoceanography, 20, PA3003, doi:10.1029/2004PA001114, 2005.

Rosenthal, Y., Boyle, E. A., and Labeyrie, L.: Last Glacial Maximum paleochemistry and deepwater circulation in the Southern Ocean: evidence from foraminiferal cadmium, Paleoceanography, 12, 787-796, 1997.

Russon, T., Elliot, M., Kissel, C., Cabioch, G., De Deckker, P., and Correge, T.: Middle-late Pleistocene deep water circulation in the southwest subtropical Pacific, Paleoceanography, 24, PA4205, doi:10.1029/2009PA001755, 2009.

Shackleton, N. J.: Carbon-13 in Uvigerina: tropical rainforest history and the Equatorial Pacific carbonate dissolution cycles, in: The Fate of Fossil Fuel $\mathrm{CO}_{2}$ in the Oceans, edited by: Andersen, N. R. and Malahoff, A., 401-428, Plenum, New York, 1977.

Shackleton, N. J. and Hall, M. A.: Oxygen and carbon isotope stratigraphy of DSDP Hole 552A: Plio-Pleistocene glacial history, Initial Rep. Deep Sea Drill. Project, 81, 599-609, 1984.

Shackleton, N. J., Berger, A., and Peltier, W. R.: An alternative astronomical calibration of the Lower Pleistocene timescale based on ODP Site 677, Trans. R. Soc. Edinburgh Earth Sci., 81, 251261, 1990.

Shackleton, N. J., Hall, M. A., and Pate, D.: Pliocene stable isotope stratigraphy of ODP Site 846, Proc. Ocean Drill. Program Sci. Results, 138, 337-356, 1995.

Sikes, E. L., Samson, C. R., Guilderson, T. P., and Howard, W. R.: Old radiocarbon ages in the Southwest Pacific Ocean during the last glacial period and deglaciation, Nature, 405, 555-559, 2000.

Skinner, L. C. and Shackleton, N. J.: An Atlantic lead over Pacific deep-water change across termination I: implications for the 
application of the marine isotope stage stratigraphy, Quat. Sci. Rev., 24, 571-580, 2005.

Talley, L.: Shallow, intermediate, and deep overturning components of the global heat budget, J. Phys. Oceanogr., 33, 530-560, 2003.

Tiedemann, R.: Acht Millionen Jahre Klimageschichte von Nordwest Afrika und Palao-Ozeanographie des angrenzenden Atlantiks, Geol.-Palaontol. Inst. und Mus., Christian-AlbrechtsUniv., Kiel, Germany, Ber. Rep. 46, 190 pp., 1991.

Toggweiler, J. R., Russell, J. L., and Carson, S. R.: Midlatitude westerlies, atmospheric $\mathrm{CO}_{2}$, and climate change during the ice ages, Paleoceanography, 21, PA2005, doi:10.1029/2005PA001154, 2006.

Venz, K. A., Hodell, D. A., Stanton, C., and Warnke, D. A.: A $1.0 \mathrm{Myr}$ record of glacial North Atlantic intermediate water variability from ODP site 982 in the Northeast Atlantic, Paleoceanography, 14, 42-52, 1999.
Venz, K. A. and Hodell, D. A.: New evidence for changes in PlioPleistocene deep water circulation from Southern Ocean ODP leg 177 site 1090, Palaeogeogr. Palaeocl., 182, 197-220, 2002.

Wang, P., Tian, J., Cheng, X., Liu, C., and Xu, J.: Major Pleistocene stages in a carbon perspective: the South China Sea record and its global comparison, Paleoceanography, 19, PA4005, doi:10.1029/2003PA000991, 2004.

Weber, S. L., Drijfhout, S. S., Abe-Ouchi, A., Crucifix, M., Eby, M., Ganopolski, A., Murakami, S., Otto-Bliesner, B., and Peltier, W. R.: The modern and glacial overturning circulation in the Atlantic ocean in PMIP coupled model simulations, Clim. Past, 3, 51-64, 2007,

http://www.clim-past.net/3/51/2007/. 